\title{
Anatomical Contributions to Hylobatid Taxonomy and Adaptation
}

\author{
Adrienne L. Zihlman • Alan R. Mootnick • \\ Carol E. Underwood
}

Received: 16 August 2010 / Accepted: 18 November 2010/Published online: 23 March 2011

(C) The Author(s) 2011. This article is published with open access at Springerlink.com

\begin{abstract}
Compared with the great apes, the small-bodied hylobatids were treated historically as a relatively uniform group with 2 genera, Hylobates and the largerbodied Symphalangus. Four genera are now recognized, each with a different chromosome number: Hoolock (hoolock) (38), Hylobates (44), Nomascus (crested gibbon) (52), and Symphalangus (siamang) (50). Previous morphological studies based on relative bone lengths, e.g., intermembral indices; molar tooth sizes; and body masses did not distinguish the 4 genera from each other. We applied quantitative anatomical methods to test the hypothesis that each genus can be differentiated from the others using the relative distribution of body mass to the forelimbs and hind limbs. Based on dissections of 13 hylobatids from captive facilities, our findings demonstrate that each of the 4 genera has a distinct pattern of body mass distribution. For example, the adult Hoolock has limb proportions of nearly equal mass, a pattern that differentiates it from species in the genus Hylobates, e.g., H. lar (lar gibbon), H. moloch (Javan gibbon), H. pileatus (pileated gibbon), Nomascus, and Symphalangus. Hylobates is distinct in having heavy hind limbs. Although Symphalangus has been treated as a scaled up version of Hylobates, its forelimb exceeds its hind limb mass, an unusual primate pattern otherwise found only in orangutans. This research provides new information on whole body anatomy and adds to the genetic, ecological, and behavioral evidence for clarifying the taxonomy of the hylobatids. The research also underscores the important contribution of studies on rare species in captivity.
\end{abstract}

Keywords Anatomy $\cdot$ Body proportions $\cdot$ Hylobates $\cdot$ Hylobatids $\cdot$ Limb mass . Symphalangus · Gibbon · Siamang · Taxonomy

A. L. Zihlman $(\bowtie) \cdot$ C. E. Underwood

Social Sciences 1, University of California, Santa Cruz, CA 95064, USA

e-mail: azihlman@ucsc.edu

A. R. Mootnick

Gibbon Conservation Center, Santa Clarita, CA 91380, USA 


\section{Introduction}

Among the apes (superfamily Hominoidea), the hylobatids have the largest number of species, yet are the least known. Current taxonomies define 4 genera with 14-19 gibbon species (Mootnick 2006; Roos et al. 2007; Thinh et al. 2010). Traditionally, gibbons and siamangs (family Hylobatidae) have been referred to as the small apes when compared to the larger-bodied and more sexually dimorphic orangutans (Pongo), gorillas (Gorilla), and chimpanzees (Pan) (family Pongidae). A. H. Schultz (1930, 1933) recognized only 2 genera: Hylobates and Symphalangus, both with long upper limbs compared to their lower limbs, small body sizes, and little sexual dimorphism, thus distinguishing them from the pongid apes. Combining information on linear variables of the skull and skeleton and on body weights, Schultz (1933) listed 7 species of Hylobates (the smaller-bodied genus) and a single species of Symphalangus (the larger-bodied genus).

Studies on karyotypes in the 1960s and 1970s confirmed generic differences between Symphalangus and Hylobates in their chromosome numbers, 50 and 44, respectively (Bender and Chu 1963; Chiarelli 1963, 1972). Nomascus (crested gibbon), formerly included with Hylobates as concolor (Creel and Preuschoft 1976; Cronin et al. 1984; Groves 1972), has 52 chromosomes (Wurster and Benirschke 1969). The hoolock gibbon with 38 chromosomes was initially placed into its own subgenus called Bunopithecus based on a fossil (Prouty et al. 1983), and later designated as Hoolock when elevated to genus level (Mootnick and Groves 2005).

More recently, molecular data show that genetic differentiation among the hylobatid species exceeds the range of difference between chimpanzees and humans (Roos and Geissmann 2001; Takacs et al. 2005; Whittaker et al. 2007). For example, molecular distances based on sequences of mtDNA show that Homo and Pan differ by $9.6 \%$; Hylobates and Hoolock, 10.3\%; Symphalangus and Hoolock, 10.6\%; Nomascus and other genera, 12.8\% (Roos and Geissmann 2001). Thus, although superficially similar in body size and long forelimbs, the hylobatids apparently differ significantly.

Anatomical studies contributed only minimally to sorting the hylobatids for at least 2 reasons. Data collected before the recognition of 4 genera (Geissmann 2002) resulted in misguided taxonomy and poorly understood findings. Second, with the exception of cranial-facial morphology (Creel and Preuschoft 1976), the 3 nonSymphalangus genera cannot be differentiated from each other morphologically with consistent results. The message from combined karyotypic and DNA studies is that differences among the hylobatid apes are not obvious in their bones, teeth, and body masses.

The present study applies a quantitative anatomical approach to the question of hylobatid taxonomy and variation. This method analyzes body mass and differentiates mammals, including primates, at the genus level and allows comparison among individuals of the same or different body masses (Grand 1977, 1978, 1990; McFarland et al. 2004). Here we test the hypothesis that each genus of hylobatid will show a distinct pattern from the others in relative distribution of body mass to the forelimbs and hind limbs. The methods promote a more detailed comparison of morphological adaptation, because relative limb masses indicate functional importance and offer insights into the individual's moving and feeding in its habitat 
(Grand 1978). In contrast, body mass alone as a single measure defines only smaller or larger and consequently cannot distinguish among the hylobatids.

\section{Materials and Methods}

The Sample

We obtained 13 individuals from captive facilities over a 30-year period, consisting of 7 Hylobates and 4 Symphalangus, and only single specimens of Hoolock and Nomascus because they are extremely rare in captivity. The sample has 6 females and 7 males, ranging in age from $6.5 \mathrm{yr}$ to $42 \mathrm{yr}$. Ted Grand contributed data for Nomascus. Body masses taken at the time of death prior to necropsy include brain and organs; we record individual body weights (Table I). We include the 6.5-yr-old as adult because he has the markers of adult: third molars (M3s) erupted and proximal humerus fused (after Bolter and Zihlman 2003). To behaviorists who study hylobatids in the wild, this age may at first appear to classify it as a subadult (Reichard and Barelli 2008), but in captivity monkeys and apes grow faster and mature earlier than their wild counterparts (Bolter and Zihlman 2010; Zihlman et al. 2004).

\section{Dissection Methods}

We use standardized methods on specimens received frozen and thawed before dissection (Grand 1977; Zihlman and McFarland 2000). We separate the entire

Table I Sample of 4 genera of Hylobatidae: Hylobates, Hoolock, Nomascus, and Symphalangus

\begin{tabular}{|c|c|c|c|c|c|c|}
\hline Species & Age & Sex & $\begin{array}{l}\text { Body weight } \\
\text { (grams) gms }\end{array}$ & $\begin{array}{l}\text { Cranial } \\
\text { capacity (cc) }\end{array}$ & $\begin{array}{l}\text { Intermembral } \\
\text { index }\end{array}$ & $\begin{array}{l}\text { Humero- } \\
\text { femoral index }\end{array}$ \\
\hline Hylobates lar & $10 \mathrm{yr}$ & male & 7570 & 116.3 & 121 & 107 \\
\hline H. lar & $41 \mathrm{yr}$ & female & 4050 & 90.3 & 125 & 110 \\
\hline H. pileatus ${ }^{\mathrm{a}}$ & $28 \mathrm{yr}$ & female & 5711 & 87.3 & 124 & 110 \\
\hline H. pileatus & $6.5 \mathrm{yr}$ & male & 6410 & n. a. & 118 & 105 \\
\hline H. moloch & $31 \mathrm{yr}$ & male & 7270 & n. a. & 116 & 105 \\
\hline H. moloch & $17 \mathrm{yr}$ & male & 7120 & 113.3 & 118 & 104 \\
\hline H. moloch & $28 \mathrm{yr}$ & female & 5600 & 98.3 & 124 & 113 \\
\hline Hoolock leuconedys & $42 \mathrm{yr}$ & female & 4950 & 95.0 & 125 & 111 \\
\hline Nomascus leucogenys & $26 \mathrm{yr}$ & female & 9500 & n. a. & n. a. & n. a. \\
\hline Symphalangus & $40 \mathrm{yr}$ & male & 10400 & 129.7 & 138 & 124 \\
\hline Symphalangus & adult & female & 7480 & 109.2 & 142 & 125 \\
\hline Symphalangus & $26 \mathrm{yr}$ & male & 7010 & 142.6 & 143 & 127 \\
\hline Symphalangus ${ }^{c}$ & subad & male & n. a. & 120.6 & 141 & 125 \\
\hline
\end{tabular}

\footnotetext{
${ }^{a}$ Died giving birth; body mass without fetus or placenta.

${ }^{\mathrm{b}}$ Some data were published from this individual in Zihlman (1984).

${ }^{\mathrm{c}}$ Cranial capacity and linear dimensions of limb bones used.
} 
forelimb at the shoulder joint and weigh it to the nearest tenth of a gram. We partition the limb into 3 pieces: the (upper) arm (separated at the elbow joint), the forearm (separated at the wrist joint), and the hand. Note that the arm is only a part of the forelimb, although in nonanatomical studies the 2 terms may be synonymous. We weigh each of the segments of the forelimb. Similarly, we separate the hind limb at the hip joint: the thigh (separated at the knee joint), the leg (separated at the ankle joint), and the foot. Note that the leg is only a part of the hind limb, although in nonanatomical studies the two terms may be synonymous.

Analysis

We determined the following:

1) Body proportions. We calculate the distribution of body mass to body segments, i.e., how much of the individual's total body mass lies in the forelimbs, the hind limbs, and the head/trunk. We calculate the contribution of both forelimbs relative to total body mass and the hind limbs to total body mass. The head/ trunk mass, along with the limbs, constitute $100 \%$ of the individual's body mass.

2) Segment proportions. We determine the distribution of mass within the forelimb and hind limb segments. Forelimb mass represents $100 \%$; we calculate the contribution of each of its parts (arm, forearm, hand) relative to total forelimb mass. Similarly, we calculate the thigh, leg, and foot, as a percent of the entire hind $\operatorname{limb}(=100 \%)$.

3) Indices. We clean the long bones with dermestid beetles, then measure, and determine indices: intermembral [ratio: forelimb (humerus + radius) to hind limb (femur+tibia)], humerofemoral (ratio: humerus to femur), brachial (ratio: radius to humerus), crural (ratio: tibia to femur).

4) We measure cranial capacity (after Bolter and Zihlman 2003) using mustard seed and report it in cubic centimeters (cc).

We were unable to obtain complete data for all individuals. Damage during necropsy to the skulls prohibited cranial capacity measures of the 6.5-yr-old Hylobates pileatus and 31-yr-old H. moloch. We did not have access to the skeleton of Nomascus, and only cranial capacity and limb bone data were available for subadult Symphalangus.

\section{Results}

\section{Body Proportions}

At the whole body level, each genus shows a distinct pattern in limb proportions relative to total body mass. Hylobates differ from the other 3 genera in having heavy hind limbs relative to body mass: mean $20.3 \%$, range $19.0-21.8 \%$. The forelimbs average $19.1 \%$ and show more variation than hind limbs (range 16.3-21.9\%, Table II). Hoolock has nearly equal mass in the forelimbs (16.5\%) and hind limbs $(16.0 \%)$, a pattern distinct from that of the other genera. With the least mass in the 
Table II Percent of total body mass distributed to segments: head/trunk, forelimb, and hind limb. (Total body $\operatorname{mass}=100 \%$.)

\begin{tabular}{lcccc}
\hline Species & Age & Head/trunk & Forelimb & Hind limb \\
\hline Hylobates lar & $10 \mathrm{yr}$ & 59.5 & 19.6 & 20.9 \\
H. lar & $41 \mathrm{yr}$ & 59.2 & 20.1 & 20.7 \\
H. pileatus & $28 \mathrm{yr}$ & 64.0 & 16.3 & 19.7 \\
H. pileatus & $6.5 \mathrm{yr}$ & 57.2 & 21.9 & 20.9 \\
H. moloch & $31 \mathrm{yr}$ & 63.2 & 17.2 & 19.6 \\
H. moloch & $17 \mathrm{yr}$ & 57.9 & 20.3 & 21.8 \\
H. moloch & $28 \mathrm{yr}$ & 62.9 & 18.1 & 19.0 \\
Hoolock leuconedys & $42 \mathrm{yr}$ & 67.5 & 16.5 & 16.0 \\
Nomascus leucogenys & $26 \mathrm{yr}$ & 65.5 & 16.6 & 17.9 \\
Symphalangus & $40 \mathrm{yr}$ & 60.2 & 22.2 & 17.6 \\
Symphalangus & $\mathrm{adult}$ & 62.1 & 20.2 & 17.7 \\
Symphalangus & $26 \mathrm{yr}$ & 63.8 & 21.1 & 15.1 \\
\hline
\end{tabular}

limbs, its head/trunk segment is the heaviest among the hylobatids. Nomascus has close to equal mass in the forelimbs (16.6\%) and hind limbs, though with slightly heavier hind limbs (17.9\%). Symphalangus combines heavy forelimbs $(21.2 \%$, range $20.2-22.2 \%$ ) with light hind limbs (16.8\%, range 15.1-17.7\%, Fig. 1).

\section{Segment Proportions}

Hoolock has relatively light proximal segments (arm, thigh) with heavy distal segments (hands, feet). Nomascus has the heaviest arm and thigh segments with light hands and feet. One individual of Hylobates overlaps Nomascus in the arm segment, but none approach its heavy thigh segment. Symphalangus differs notably from the other genera in its light arm and heavy forearm segments. Its thigh is light and the foot heavy, a pattern that also sets it apart from the others (Fig. 2a, b).

\section{Body Mass}

The Hylobates average $6247.3 \mathrm{~g}$ (range 4050.0-7570.0); Hoolock 4950.0; Nomascus 9500.0; Symphalangus 8940.0 (7480.0-10,400.0).

\section{Indices}

The Intermembral index for Hylobates averages 120.9 for our 7 individuals (range 116-125); 107.7 for humerofemoral (104-113); 110.4 for brachial (108-112); and 88.3 for crural (84-93). For Hoolock the index is 125 for intermembral, 111 for humerofemoral, 109 for brachial, and 86 for crural. The index for Symphalangus averages 141 for intermembral (138-143); 125.3 for humerofemoral (124-127); 106.8 brachial (105-109); and 83.5 for crural (83-84). 
Fig. 1 Means of head/trunk, forelimb, and hind limb mass distribution as percent of total body mass.

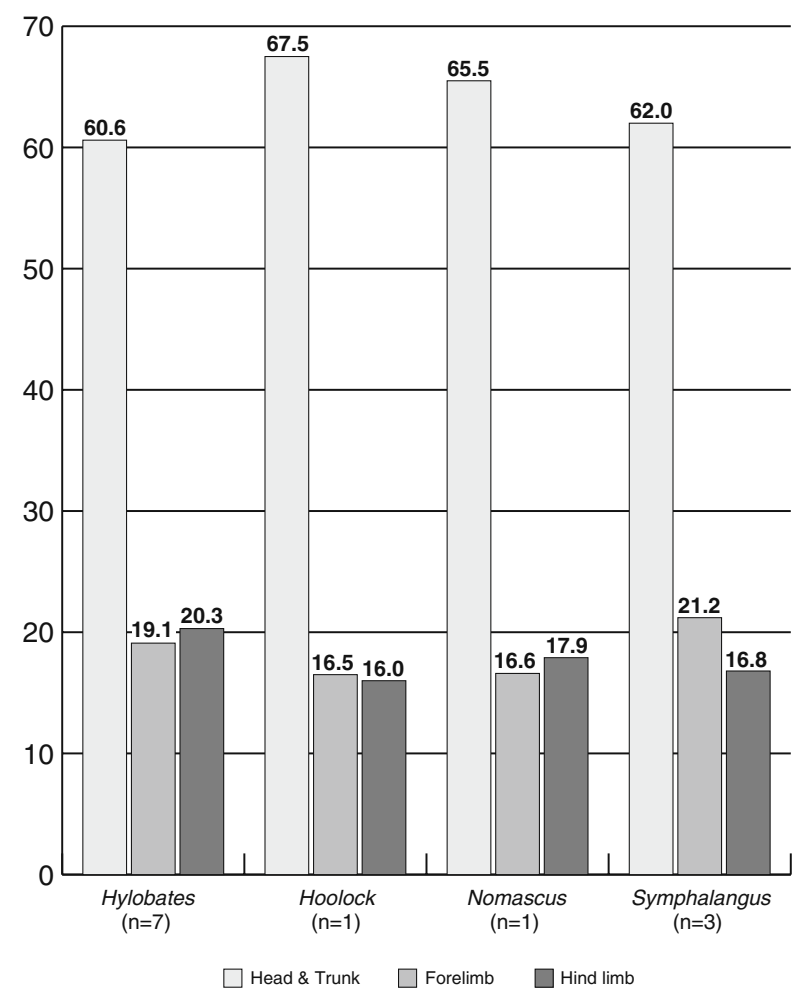

Cranial Capacities

Hylobates average 101.1 (87.3-116.3); Hoolock, 95; and Symphalangus, 125.5 (109.2-142.6).

\section{Discussion}

Discriminating among the 3 non-Symphalangus genera is particularly challenging, given the paucity of data on Hoolock and Nomascus. By taking the whole body as the focus of analysis, we here distinguish Hylobates, Hoolock, Nomascus, and Symphalangus from each other in relative body mass distribution to the limbs. This finding adds a useful anatomical dimension to taxonomy, suggests functional differences, and acts as a guide for future studies.

Within our sample of Hylobates, individuals vary in age, sex, reproductive state, and body mass; however, close examination shows that Hylobates conform to a pattern that is distinct from that of the other 3 genera. For example, in relative forelimb mass the 28-yr-old pregnant Hylobates pileatus and the 6.5-yr-old male $H$. pileatus represent the 2 ends of the range, whereas their heavy hind limbs fall with the other Hylobates. Even with very different ages and body masses, the 10-yr-old male Hylobates lar and 41-yr-old female Hylobates lar have relative limb masses that are nearly identical. This 41-yr-old female Hylobates is similar in age and body 
Fig. 2 (a) Means and ranges of arm, forearm, and hand segments as percent of total forelimb mass. (b) Means and ranges of thigh, leg, and foot segments as percent of total hind limb mass.

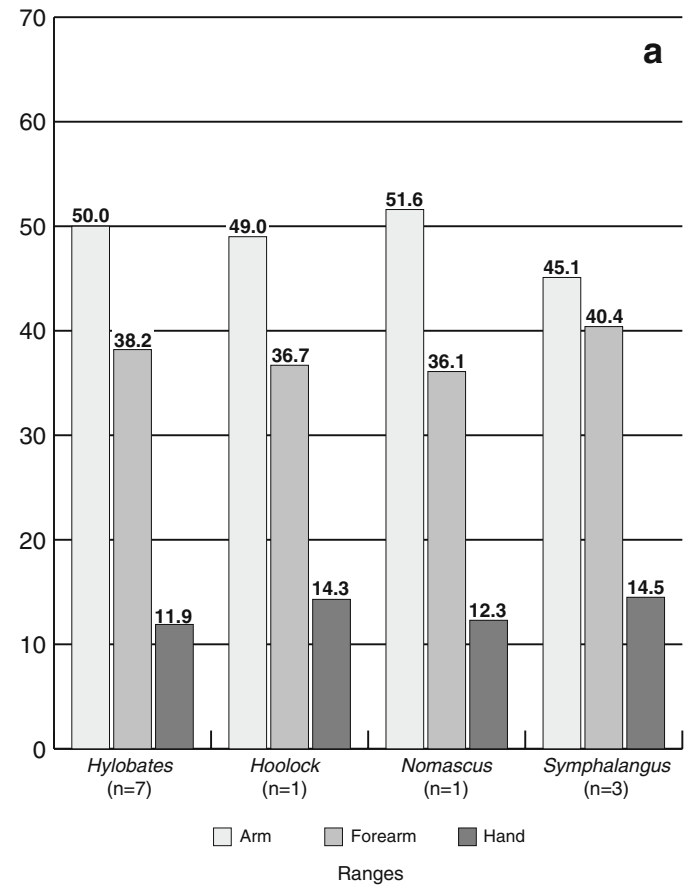

Hylobates: Arm (46.6-55.6); Forearm (32.9-40.6); Hand (9.4-13.4) Symphalangus: Arm (43.4-47.4); Forearm (38.4-42.3); Hand (14.2-15.0)

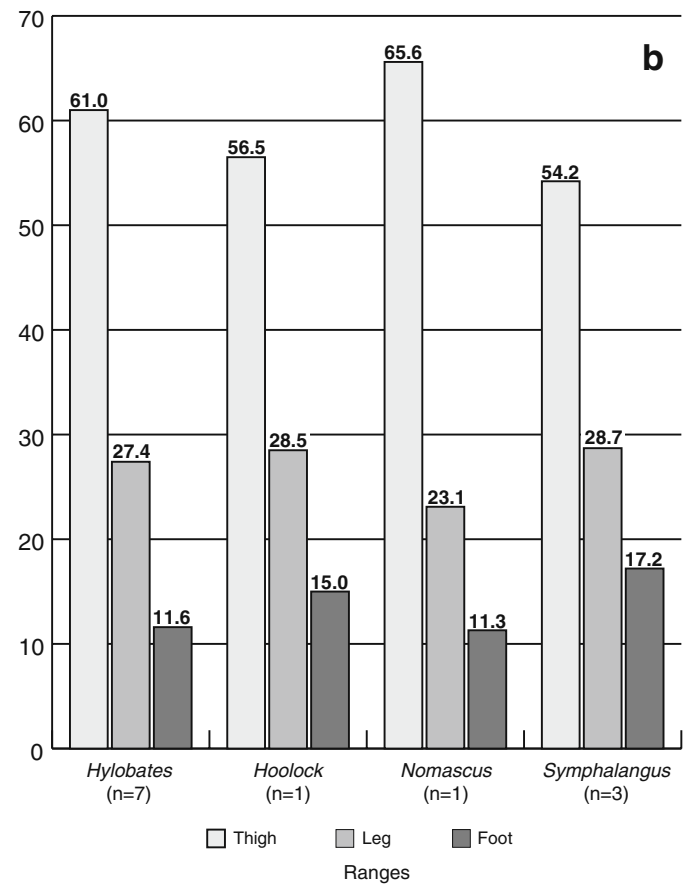

Hylobates: Thigh (55.0-64.5); Leg (24.8-30.9); Foot (9.9-14.1)

Symphalangus: Thigh (53.8-54.4); Leg (25.8-30.7); Foot (15.0-20.4) 
mass to the 42-yr-old female Hoolock, yet devotes more body mass to the limbs, and the 2 genera contrast in their proportions. In addition, differences in state of health do not alter proportions. For example, in Symphalangus - adult female, old male, and young male that was ill and lost weight - their heavy forelimbs and lighter hind limbs conform closely to a species-specific pattern and contrast with Nomascus, which is similar in body mass to the old male.

The analysis within the limb segments also shows distinctions, though less than those for whole body proportions. Nomascus has a heavy thigh and light leg, unlike the other genera, and Hoolock is distinct from Hylobates in its relatively heavy hands and feet. Across the genera, Symphalangus has similar mass in its arm and forearm segments, and in its light thigh and heavy foot. The combination of proportions of the whole body and proportions within the limbs gives each genus an anatomical fingerprint that is a useful taxonomic marker.

Body mass, cranial capacity, dentition, and long bone indices vary and overlap in the hylobatids and do not show consistent findings useful for taxonomic purposes. The compiled data highlight the problems (Table III). Body mass is not reliable as a taxonomic feature because it is so variable; it fluctuates throughout an individual's life, particularly in adult females during reproduction. It is not surprising then that body mass in this sample of 13 overlaps considerably among the genera. For example, Hoolock fits within the range of Hylobates, the female Nomascus is in the range of Symphalangus, and the female Symphalangus is in the range of Hylobates. In measurements of cranial capacity, some individuals of Symphalangus are in the range of Hylobates. No information is available on cranial capacity for Nomascus.

Similarly, dental dimensions do not distinguish among the genera (Frisch 1973). For example, averages of mesiodistal diameters of permanent molars overlap in Hylobates lar, Hoolock, and Symphalangus (1973, p. 76). This finding led Frisch to conclude that "there is a continuum in the size of the dentition between the smallest and the largest-toothed living species of the hylobatid families... This observation makes it clear that for taxonomic purposes, no exclusive reliance should be set on measurements independent of a consideration of the morphology" (1973, p. 77). In addition to cranial capacity and dentition, intermembral indices overlap among the genera and therefore are unreliable for taxonomy. The intermembral index of Hylobates (116-125) in our sample encompasses Hoolock (125). Likewise, Nomascus intermembral indices from the literature $(141.1,140.3)$ fall comfortably into our range for Symphalangus (138-143).

\section{Body Proportions and Locomotor Function}

The distinct pattern of limb masses described for each of the 4 genera suggests functional correlates and corresponding differences in locomotor patterns. Where there is information from the wild, descriptions of locomotor behavior of Hylobates and Symphalangus show differences that correspond to their anatomical divergences (Caldecott 1980; Chivers 1972; Ellefson 1967, 1974; Fleagle 1976; Gittins 1983). The well developed forelimbs and particularly the heavy hind limbs promote flexibility in posture and locomotion of Hylobates moving through the forest canopy, described and illustrated by Grand $(1972,1984)$ based on John Ellefson's films on wild Hylobates lar. Movements are whole body actions: suspension under branches, 


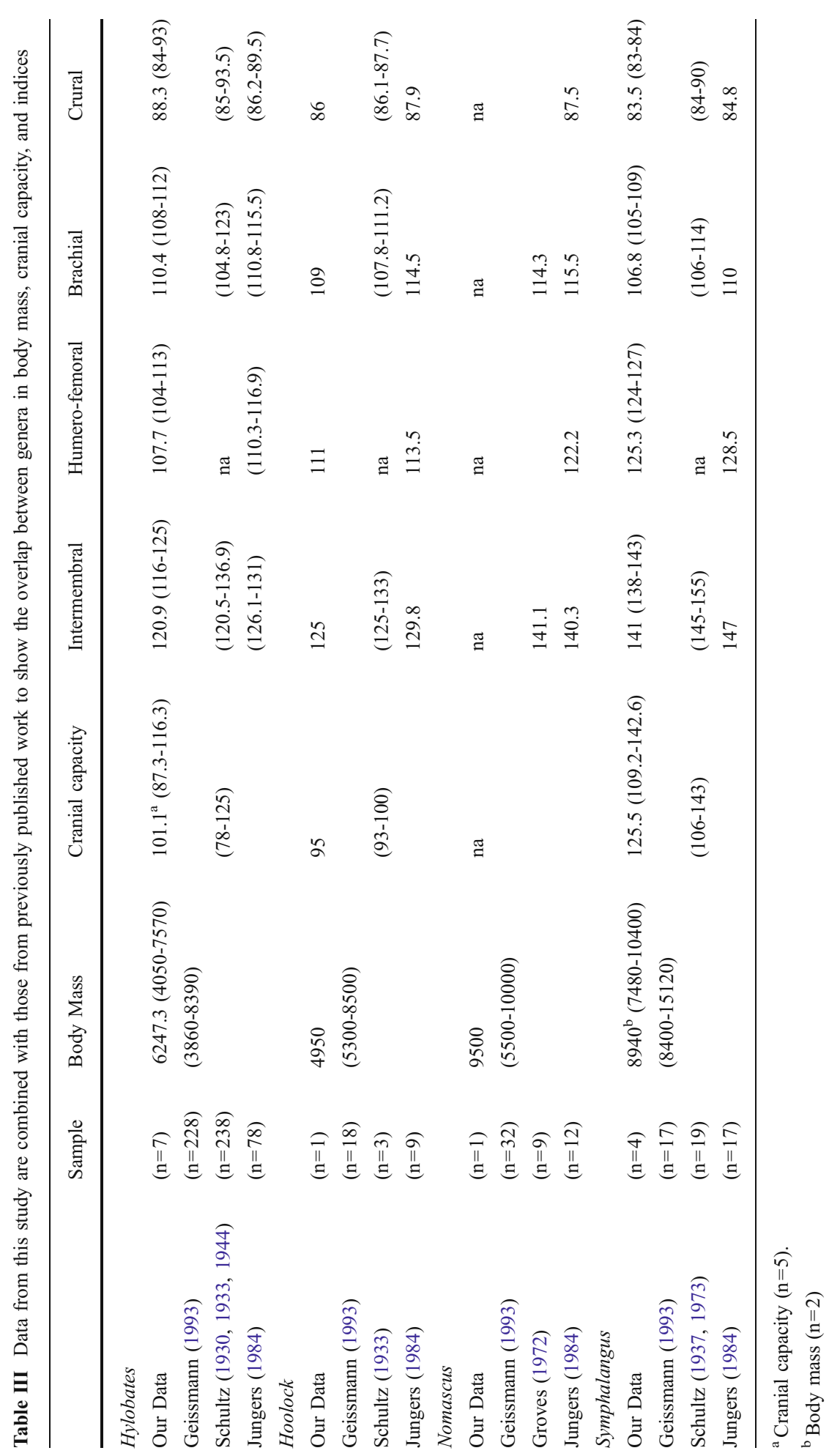


fast ricochetal swinging across the upper canopy, propulsive action of the hind limbs that contributes to speed and the ricochet effect, climbing and descending trees, leaping across large gaps in the canopy, and moving bipedally across tree limbs. Hylobates prefer open canopy and are uniquely able to navigate the discontinuous forests with their agile, strong hind limb leaps (Caldecott 1980; Gittins 1983).

Field data for Hylobates serve as comparison with Symphalangus, whose heavy forelimbs and less massive hind limbs are adapted to forelimb-dominated climbing. In contrast to Hylobates, Symphalangus do not engage in fast brachiation and thrust little with the hind limbs in propulsion and leaping (Fleagle 1976). Further, they are unable to cross horizontal gaps much more than $10 \mathrm{~m}$ and more often use a 3-limbed support stance $72 \%$ of the time, vs. gibbons at $40 \%$ (Fleagle 1976). Siamangs leap and cross discontinuities in the forest less often; they make use of a more closed canopy and persist in these denser vegetations that support fewer large-branch pathways but offer multiple, smaller supports for moving and resting (Caldecott 1980; Fleagle 1976).

\section{Summary and Conclusions}

The anatomical data on body proportions and limb masses presented here distinguish the genera Hylobates, Hoolock, Nomascus, and Symphalangus from each other and therefore contribute information useful for taxonomy. However, additional wholebody anatomical data on a larger sample of individuals, especially Hoolock and Nomascus, will further clarify or elaborate the extent to which the genera differ.

The majority of hylobatid species are endangered, with some critically endangered. Hoolock and Nomascus are limited in their distribution in the wild, with some species numbering 20 and 110 (Chan et al. 2005; Long and Nadler 2009; Mootnick et al. 2007). Of the 10 gibbon species housed in North America, there are $<20$ individuals in 6 of those species.

The value of studies on captive rare primates is emphasized by the attention given to these individuals during their lives. Our specimens come from captive facilities that practice exceptional care in animal husbandry and offer seminaturalistic habitats that allow the individuals free range of locomotor expression (Doolittle and Grand 1995; Fernandez and Timberlake 2008). Even after death, these individuals, infrequently available for anatomical studies, can reveal additional insights about variation and adaptation and lay the foundation for hypotheses that can be tested in the field. The yet unexplored behavior, ecology, and anatomy of so many populations of hylobatids highlight the importance of conservation and continued study of these less known apes.

\section{Future Research}

Though studies on locomotor behavior have been few, available field data on Hylobates and Symphalangus show correspondences between limb proportions and locomotor function. Given the new anatomical data, we hypothesize that future field studies will uncover locomotor profiles that will show additional differences. Few field observations mention locomotor behavior of Hoolock, though its divergent 
anatomical configuration suggests that its posture and locomotion may also show subtle distinctions from other genera. The locomotor behavior of Nomascus is also relatively unknown; their body and limb proportions, particularly the heavy arm and thigh segments, indicate power in shoulder, hip, and knee motions that can be assessed in the field. Future field studies that direct attention to posture and locomotion will likely find distinctions among the genera by making connections between locomotor anatomy and activity budget, foraging behavior, daily range size, forest level, and substrate size. Such research may clarify the specific adaptation of each genus and further our understanding of how so many species of hylobatids evolved and adapted to a wide range of habitats in Southeast, east, and south Asia.

Acknowledgments We thank the following institutions and staff for lending us archival specimens and records for our study: Yerkes National Primate Research Center; Lynn Barkley and the Los Angeles County Museum of Natural History; and Ted Grand, Smithsonian, National Zoo. We appreciate dissection assistance from Lynda LaBrecque, Robin McFarland, and Debra Bolter. Richard Baldwin, UCSC laboratory manager, provided logistical assistance. We thank the editor, 2 anonymous reviewers, Debra Bolter, and Tessa Toscano for comments on the manuscript. We thank the Division of Social Sciences, University of California, Santa Cruz for financial support.

Open Access This article is distributed under the terms of the Creative Commons Attribution Noncommercial License which permits any noncommercial use, distribution, and reproduction in any medium, provided the original author(s) and source are credited.

\section{References}

Bender, M. A., \& Chu, E. H. Y. (1963). The chromosomes of primates. In Evolutionary and genetic biology of primates, Vol. I (pp. 261-310). New York: Academic Press.

Bolter, D., \& Zihlman, A. (2003). Morphological analysis of growth and development in wild-collected vervet monkeys (Cercopithecus aethiops) with implications for growth patterns in Old World monkeys, apes, and humans. Journal of Zoology (London), 260, 99-110.

Bolter, D., \& Zihlman, A. (2010). Primate growth and development. A functional and evolutionary approach. In C. J. Campbell, A. Fuentes, K. C. MacKinnon, S. K. Bearder, \& R. M. Stumpf (Eds.), Primates in perspective (2nd ed., pp. 428-439). New York: Oxford University Press.

Caldecott, J. O. (1980). Habitat quality and populations of two sympatric gibbons (Hylobatidae) on a mountain in Malaya. Folia Primatologica, 33, 291-309.

Chan, B. P. L., Fellowes, J. R., Geissmann, T., \& Zhang, J. (2005). Hainan gibbon status survey and conservation action plan, version 1, Kadoorie Farm \& Botanic Garden Technical Report No. 3 (p. iii + 32). Hong Kong: Kadoorie Farm \& Botanic Garden.

Chiarelli, B. (1963). Comparative morphometric analysis of the primates chromosomes. III. The chromosomes of genera Hylobates, Colobus and Presbytis. Caryologia, 16, 637-648.

Chiarelli, B. (1972). The karyotypes of the gibbons. In D. M. Rumbaugh (Ed.), Gibbon and siamang, Vol. $I$ (pp. 90-102). Basel: Karger.

Chivers, D. (1972). The siamang and the gibbon in the Malay Peninsula. In D. M. Rumbaugh (Ed.), Gibbon and siamang, Vol. I (pp. 103-135). Basel: Karger.

Creel, N., \& Preuschoft, H. (1976). Cranial morphology of the lesser apes: A multivariate statistical study. In D. M. Rumbaugh (Ed.), Gibbon and siamang, Vol IV (pp. 219-303). Basel: Karger.

Cronin, J. E., Sarich, V. M., \& Ryder, O. (1984). Molecular evolution and speciation in the lesser apes. In H. Preuschoft, D. J. Chivers, W. Y. Brockelman, \& N. Creel (Eds.), The lesser apes (pp. 467-485). Edinburgh: Edinburgh University Press.

Doolittle, R. L., \& Grand, T. I. (1995). Benefits of the zoological park to the teaching of comparative vertebrate anatomy. Zoo Biology, 14, 453-462.

Ellefson, J. O. (1967). A natural history of gibbons in the Malay Peninsula. Ph.D. Thesis, University of California at Berkeley. 
Ellefson, J. O. (1974). A natural history of white-handed gibbons in the Malayan Peninsula. In D. M. Rumbaugh (Ed.), Gibbon and siamang, Vol. III (pp. 1-136). Basel: Karger.

Fernandez, E. J., \& Timberlake, W. (2008). Mutual benefits of research collaborations between zoos and academic institutions. Zoo Biology, 6, 470-487.

Fleagle, J. G. (1976). Locomotion and posture of the Malayan siamang and implications for hominoid evolution. Folia Primatologica, 26, 245-269.

Frisch, J. E. (1973). The hylobatid dentition. In H. Preuschoft, D. J. Chivers, W. Y. Brockelman, \& N. Creel (Eds.), Gibbon and siamang, Vol. II (pp. 55-95). Basel: Karger.

Geissmann, T. (1993). Evolution of communication in gibbons (Hylobatidae). Ph.D. dissertation. Universitat Zurich.

Geissmann, T. (2002). Taxonomy and evolution of gibbons. Evolutionary Anthropology, Supplement, 1, 28-31.

Gittins, S. P. (1983). Use of the forest canopy by the agile gibbon. Folia Primatologica, 38, 39-71.

Grand, T. I. (1972). A mechanical interpretation of terminal branch feeding. Journal of Mammalogy, 53, 198-201.

Grand, T. I. (1977). Body weight: Its relation to tissue composition, segment distribution, and motor function. Interspecific comparisons. American Journal of Physical Anthropology, 47, 211-239.

Grand, T. I. (1978). Adaptations of tissue and limb segments to facilitate moving and feeding in arboreal folivores. In G. G. Montgomery (Ed.), The ecology of arboreal folivores (pp. 231-241). Washington: Smithsonian Institution Press.

Grand, T. I. (1984). Motion economy within the canopy: Four strategies for mobility. In P. S. Rodman \& J. G. H. Cant (Eds.), Adaptations for foraging in nonhuman primates: Contributions to an organismal biology of prosimians, monkeys, and apes (pp. 54-72). New York: Columbia University Press.

Grand, T. (1990). The functional anatomy of body size. In J. Damuth \& B. J. MacFadden (Eds.), Body size in mammalian paleobiology: Estimation and biological implications (pp. 39-47). Cambridge: Cambridge University Press.

Groves, C. P. (1972). Systematics and phylogeny of gibbons. In D. M. Rumbaugh (Ed.), Gibbon and siamang, Vol. I (pp. 1-89). Basel: Karger.

Jungers, W. L. (1984). Scaling of the hominoid locomotor skeleton with special reference to lesser apes. In H. Preuschoft, D. J. Chivers, W. Y. Brockelman, \& N. Creel (Eds.), The lesser apes (pp. 146-169). Edinburgh: Edinburgh University Press.

Long Yoncheng, \& Nadler, T. (2009). Eastern black crested gibbon Nomascus nasutus (Kunkel d'Herculais, 1884). In R. A. Mittermeier, J. Wallis, A. B. Rylands, J. U. Ganzhorn, J. F. Oates, E. A. Williamson, et al. (Eds.), Primates in peril: The world's 25 most endangered primates, 2008-2010. Primate Conservation, 24, 26-27.

McFarland, R. K., Sousa, M., \& Zihlman, A. L. (2004). Anatomical components of locomotion in five genera of apes. A preliminary overview. American Journal of Physical Anthropology, Supplement, 38, 145.

Mootnick, A. R. (2006). Gibbon (Hylobatidae) species identification recommended for rescue and breeding centers. Primate Conservation, 21, 103-138.

Mootnick, A., \& Groves, C. (2005). A new generic name for the hoolock gibbon (Hylobatidae). International Journal of Primatology, 26, 971-976.

Mootnick, A. R., Wang, X. M., Moisson, P., Chan, B. P. L., Fellowes, J. R., \& Nadler, T. (2007). Hainan gibbon (Nomascus hainanus) (Thomas, 1892) China (Island of Hainan). In R. A. Mittermeier, J. Ratsimbazafy, A. B. Rylands, L. Williamson, J. F. Oates, D. Mbora, et al. (Eds.), Primates in peril: The world's 25 most endangered primates, 2006-2008. Primate Conservation, 22, 16-17.

Prouty, L. A., Buchanan, P. D., Pollitzer, W. S., \& Mootnick, A. R. (1983). Taxonomic note. Bunopithecus: A genus-level taxon for the hoolock gibbon (Hylobates hoolock). American Journal of Primatology, 5, 83-87.

Reichard, U. H., \& Barelli, C. (2008). Life history and reproductive strategies of Khao Yai Hylobates lar: Implications for social evolution in apes. International Journal of Primatology, 29, 823-844.

Roos, C., \& Geissmann, T. (2001). Molecular phylogeny of the major hylobatid divisions. Molecular Phylogentics and Evolution, 19, 486-494.

Roos, C., Thanh, Vu Ngoc, Walter, L., \& Nadler, T. (2007). Molecular systematics of Indochinese primates. Vietnamese Journal Primatology, 1, 41-53.

Schultz, A. H. (1930). The skeleton of the trunk and limbs of higher primates. Human Biology, 2, 303438.

Schultz, A. H. (1933). Observations on the growth, classification and evolutionary specialization of gibbons and siamangs. Human Biology, 5(212-255), 385-428. 
Schultz, A. H. (1937). Proportions, variability and asymmetries of the long bones of the limbs and the clavicles in man and apes. Human Biology, 9, 281-328.

Schultz, A. H. (1944). Age changes and variability in gibbons: A morphological study on a population sample of a man-like ape. American Journal Physical Anthropology, 2, 1-129.

Schultz, A. H. (1973). The skeleton of the Hylobatidae and other observations on their morphology. In D. M. Rumbaugh (Ed.), Gibbon and siamang, Vol. II (pp. 1-54). Basel: Karger.

Takacs, Z., Morales, J. C., Geissmann, T., \& Melnick, D. J. (2005). A complete species-level phylongeny of the Hylobatidae based on mitochondrial ND3-ND4 gene sequences. Molecular Phylogenetics and Evolution, 36, 456-467.

Thinh, V. N., Mootnick, A. R., Geissmann, T., Li, M., Ziegler, T., Agil, M., et al. (2010). Mitochondrial evidence for multiple radiations in the evolutionary history of small apes. BMC Evolutionary Biology, $10,1-13$.

Whittaker, D. J., Morales, J. C., \& Melnick, D. J. (2007). Resolution of the Hylobates phylogeny: Congruence of mitochondrial D-loop sequences with molecular, behavioral, and morphological data sets. Molecular Phylogenetics and Evolution, 45, 620-628.

Wurster, D. H., \& Benirschke, K. (1969). Chromosomes of some primates. Mammal. Chromosome Newsletter, 10, 3.

Zihlman, A. L. (1984). Body build and tissue composition in Pan paniscus and Pan troglodytes with comparisons to other hominoids. In R. L. Susman (Ed.), The pygmy chimpanzee: Evolutionary morphology and behavior (pp. 179-200). New York: Plenum Press.

Zihlman, A. L., \& McFarland, R. K. (2000). Body mass in lowland gorillas: A quantitative analysis. American Journal Physical Anthropology, 113, 61-78.

Zihlman, A., Bolter, D., \& Boesch, C. (2004). Wild chimpanzee dentition and its implications for assessing life history in immature hominin fossils. Proceedings of the National Academy of Sciences, $101,10541-10543$. 